\title{
PENGARUH SUHU ESTERIFIKASI TERHADAP KARAKTERISTIK KARBOKSIMETIL KITOSAN (CMCts)
}

\author{
Dwiyitno, Jamal Basmal dan Mulyasari"
}

\begin{abstract}
ABSTRAK
Sifat kitosan yang hanya larut dalam asam lemah menjadi kendala pada pemanfaatannya secara luas. Seperti diketahui banyak produk aplikasi kitosan yang menuntut kitosan yang bersifat larut dalam air seperti pada produk-produk kosmetik, pangan dan farmasi. Salah satu turunan kitosan yang bersifat larut dalam air adalah karboksimetil kitosan (CMCts) yang merupakan salah satu bentuk modifikasi kitosan yang diperoleh melalui proses karboksimetilasi kitosan dengan monokloroasetat dalam kondisi alkali. Pada penelitian ini poses produksi CMCts dilakukan berdasarkan metode Bader \& Birkholz (1997). Kitosan kasar direndam dalam $\mathrm{NaOH}$, kemudian ditambah monokloroasetat. Selanjutnya dilakukan esterifikasi dengan perlakuan suhu yaitu 30 , 50 dan $90^{\circ} \mathrm{C}$ selama 60 menit. Kemudian $\mathrm{pH}$ larutan diatur menjadi 5 dan dicuci dengan metanol. Produk dikeringkan dengan oven pada suhu $50^{\circ} \mathrm{C}$. Hasil penelitian menunjukkan bahwa seluruh produk larut dalam air meskipun dengan tingkat kelarutan yang bervariasi, yaitu antara 65,7$97,9 \%$. Viskositas CMCts bervariasi antara 45,6 sampai $65,2 \mathrm{cps}$ dengan rendemen $57,0-98,1 \%$. CMCts yang dihasilkan dari seluruh perlakuan memiliki $\mathrm{pH} 5$ dengan penampakan kuning keputihan sampai kuning kecoklatan.
\end{abstract}

\section{ABSTRACT: Effect of esterification temperature on the characteristics of carboxymethyl chitosan (CMCts). By: Dwiyitno, Jamal Basmal and Mulyasari}

The characteristic of chitosan which is only soluble in weak acid has become an obstacle to its broad application, since the utilization of chitosan for food, pharmaceutical and cosmetics purposes needs chitosan that soluble in water. One of the chitosan derivatives which water soluble is carboxymethyl chitosan (CMCts). CMCts can be obtained by carboxymethylating chitosan with monochloroacetic acid in alkaline condition. CMCts was produced based on the method developed by Bader \& Birkholz (1997). Firstly, crude chitosan was dipped in alkaline solution and added with monochloroacetic acid. It was then refluxed at 30,50 and $90^{\circ} \mathrm{C}$ for 60 minutes. Afterwards, the $\mathrm{pH}$ was adjusted to 5 and the product was washed with methanol and dried at $50^{\circ} \mathrm{C}$. The results showed that all of the products were soluble in water at various level (65.7 - 97.9\%). Viscosity of CMCts were between 45.6 to $65.2 \mathrm{cps}$, whereas the yields were $57.0-98.1 \%$. The appearance of CMCts was whitish-yellow to brownish-yellow and the pH value of all CMCts were 5

KEYWORDS: carboxymethyl chitosan, esterification, viscosity, shrimp-waste chitosan

\section{PENDAHULUAN}

Kitosan merupakan produk hasil pemanfaatan limbah krustasea yang dapat digunakan pada berbagai bidang industri seperti farmasi, pangan, pertanian, tekstil dan kimia. Bila dilarutkan dalam asam lemah, kitosan akan menjadi polimer kationik dengan struktur linier sehingga dapat digunakan pada proses flokulasi, pembentuk film dan imobilisasi bakteri/enzim (Ornum, 1992). Selanjutnya karakteristik kitosan sebagai polielektrolit dapat digunakan sebagai koagulan limbah maupun pengkelat logam berat (Bough, 1975; Sandford, 1988).

Sifat kitosan yang hanya larut dalam asam lemah menjadi kendala pada pemanfaatannya secara luas.
Seperti diketahui banyak produk aplikasi kitosan yang menuntut kitosan yang bersifat larut dalam air seperti pada produk-produk kosmetik, pangan dan farmasi. Asam memiliki sifat yang dapat menyebabkan iritasi pada kulit serta menimbulkan bau yang tidak sedap (Alamsyah, 2000). Kitosan larut air atau dikenal dengan karboksi metil kitosan (CMCts) merupakan salah satu turunan (derivat) kitosan yang bersifat larut dalam air. CMCts tidak beracun serta bersifat biodegradable dan biocompatible.

CMCts banyak dimanfaatkan pada bidang farmasi dan kesehatan seperti hydrogel, cholesterol reducer dan antimikroba/antibakteri (Davies et al., 1988; Muzzarelli et al., 1997 ; Zhai et al., 2003). Di bidang pangan CMCts dapat digunakan sebagai edible coat-

Peneliti pada Pusat Riset Pengolahan Produk dan Sosial Ekonomi Kelautan dan Perikanan 
ing dan antioksidan. Sebagai antioksidan, CMCts dapat mencegah warmed-over flavour (WAF) pada pengolahan daging sapi (St. Angelo \& Vercellotti, 1989). Pada penggunaan 5000 ppm CMCts dapat menurunkan $93 \%$ kandungan asam tiobarbiturat (TBA)

Produksi CMCts dilakukan melalui penambahan monokloroasetat terhadap kitosan pada kondisi alkali (Bader \& Birkholz, 1997). Sementara itu Davies et al. (1989) melakukan penelitian produksi kitin larut air (NOCC) melalui reaksi antara kitosan dengan monokloroasetat pada fase padat. Penambahan monokloroasetat berfungsi untuk mengganti ion $\mathrm{H}^{+}$ pada gugus hidroksi $(\mathrm{OH})$ dan gugus amin $\left(\mathrm{NH}_{2}\right)$. Pada kondisi alkali reaksi kitosan dengan monokloroasetat akan menghasilkan karboksimetil kitosan sebagai berikut (Bader \& Birkholz, 1997):

$$
\begin{gathered}
\text { Kitosan }+2 \mathrm{Cl}_{-} \mathrm{CH}_{2} \mathrm{COOH}+2 \mathrm{NaOH} \rightarrow \mathrm{CMCts}+ \\
2 \mathrm{H}_{2} \mathrm{O}+2 \mathrm{NaCl}
\end{gathered}
$$

Pada penelitian Sashiwa dalam Alamsyah (2000), proses karboksimetilasi dilakukan dengan menggunakan dimetilasetamid (DMAc) dan litium klorida ( $\mathrm{LiCl}$ ) untuk mengubah struktur kitosan. Selanjutnya pengeringan dilakukan dengan panas matahari. Produksi CMCts juga dapat dilakukan dengan menambahkan asam asetat glasial (1:1) dan glioksilik dengan perbandingan amina/glioksilik 1: 9 (Muzzarelli, 1977). Wuriyandari (2002), melakukan proses karboksimetilasi dengan iso propanol (IPA) dan $\mathrm{NaOH}$ kemudian dilanjutkan dengan esterifikasi dengan asam monokloroasetat pada suhu $55^{\circ} \mathrm{Cselama} 5 \mathrm{jam}$. Campuran dicuci dengan metanol dan dikeringkan pada suhu $60^{\circ} \mathrm{C}$. Sementara itu Chen \& Park (2003) melakukan penelitian yang sama pada berbagai perlakuan suhu, yaitu $0-60^{\circ} \mathrm{C}$

Pada penelitian ini akan dilihat pengaruh suhu esterifikasi terhadap karakteristik CMCts. Esterifikasi dilakukan dengan menggunakan asam monokloroasetat. Asam monokloroasetat dipilih karena lebih murah dan mudah diperoleh daripada DMAC dan LiCl. Penggunaan suhu tinggi diharapkan dapat meningkatkan optimalisasi reaksi esterifikasi dan mempersingkat waktu proses sehingga dapat meningkatkan efisiensinya.

\section{BAHAN DAN METODE}

Pada penelitian ini digunakan limbah udang windu (Penaeus monodon) dari Muara Baru sebagai bahan baku. Kitosan dibuat melalui proses deproteinasi limbah dilanjutkan dengan demineralisasi dan deasetilasi. Deproteinasi dilakukan dengan menggunakan $\mathrm{NaOH}$ teknis $10 \%$ pada suhu $70^{\circ} \mathrm{C}$ selama 1 jam (Fawzya et al., 2003). Demineralisasi dilakukan dengan $\mathrm{HCl}$ teknis $10 \%$ pada suhu kamar selama $1 \mathrm{jam}$. Setelah dijemur hingga kering akan diperoleh kitin. Kitosan kasar diperoleh melalui deasetilasi kitin dengan $\mathrm{NaOH}$ teknis $50 \%$ selama 72 jam pada suhu $70^{\circ} \mathrm{C}$. Setelah dicuci hingga $\mathrm{pH}$ netral kemudian dijemur hingga kering dan akhirnya diperoleh kitosan kasar.

Proses produksi CMCts dilakukan berdasarkan metode Bader \& Birkholz (1997). Kitosan kasar direndam dalam $\mathrm{NaOH}$ teknis $30 \%$ untuk membentuk suasana alkali. Kemudian terhadap kitosan yang digunakan ditambah monokloroasetat dengan perbandingan 1:1. Proses esterifikasi dilakukan sesuai perlakuan yaitu pada suhu 30,50 dan $90^{\circ} \mathrm{C}$ selama 60 menit. Setelah dingin dilakukan pengaturan $\mathrm{pH}$ menjadi 5 dan presipitasi dilakukan dengan metanol teknis. Pengeringan dilakukan dengan oven pada suhu $55^{\circ} \mathrm{C}$. Terhadap produk yang dihasilkan diamati rendemen, kadar air (oven), derajat asetilasi (DA), viskositas, kelarutannya dalam air serta penampakannya. Analisis yang sama juga dilakukan terhadap kitosan sebelum dikarboksimetilasi sebagai pembanding. Untuk mengukur viskositas dan kelarutannya, kitosan dilarutkan dalam asam asetat $1 \%$.

DA diukur dengan Fourier Transform Infra Red (FTIR) spectrometer (Perkin Elmer model Spectrum One). Sebelum dibaca, sampel dibuat dalam bentuk film terlebih dahulu. Sebanyak $2 \mathrm{mg}$ sampel di tambah dengan $200 \mathrm{mg} \mathrm{KBr}$ lalu digerus sampai halus. Campuran tersebut selanjutnya dimasukkan ke dalam alat pencetak pelet dan dipres dengan tekanan 7-8 ton sambil divakum untuk menarik uap air yang ada. Film kemudian dibaca pada $450-4000 \mathrm{~cm}^{-1}$. Data ratarata absorbansi dari 5 kali ulangan pembacaan pada spektrum di sekitar $1650 \mathrm{~cm}^{-1}$ dan $3450 \mathrm{~cm}^{-1}$ dijadikan dasar untuk menghitung DA. Spektrum di sekitar 1650 $\mathrm{cm}^{-1}$ menunjukkan gugus amida sedangkan 3450 $\mathrm{cm}^{-1}$ menunjukkan gugus hidroksil. Rumus untuk menghitung DA adalah sebagai berikut (Muzzarelli et al., 1997)

$$
D A(\%)=\frac{A_{1650}}{A_{3450}} \times \frac{1}{1,33}
$$

$$
\text { dimana Derajat Deasetilasi }(D D)=100-D A
$$

Viskositas diukur dengan alat Brookfield viscometer (model LVF seri:88883). Spindel yang digunakan adalah spindel no. 2 dengan kecepatan 30 rpm. Untuk kitosan dilarutkan dalam asam asetat $1 \%$ dengan konsentrasi $1 \%$ pada suhu kamar, sedangkan CMCts dilarutkan dalam akuades dengan konsentrasi $1 \%$ pada suhu kamar juga (Kyoon et al., 2003). 


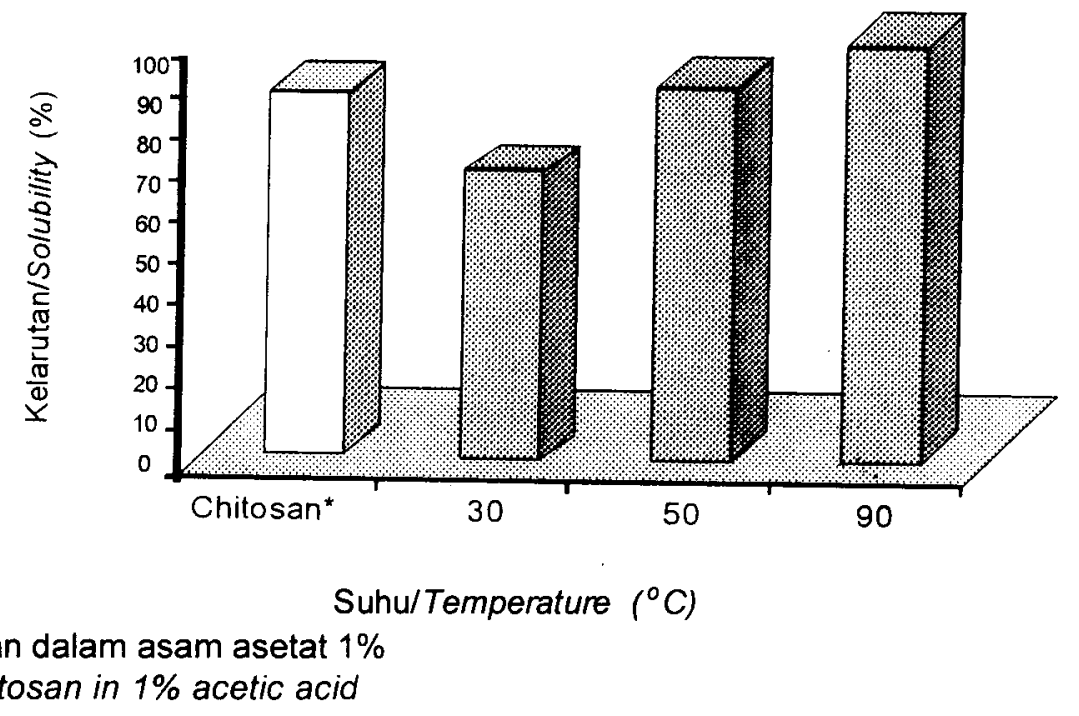

Gambar 1. Kelarutan CMCts dari berbagai perlakuan suhu dan kitosan pembanding.

Figure 1. Solubility of $\mathrm{CMCts}$ of various temperature treatment and chitosan as reference.

Kelarutan diukur berdasarkan modifikasi metode Lembono (1989). Sebanyak 1\% CMCts dilarutkan dalam akuades pada suhu kamar, kemudian disaring dengan planktonet 200 mesh. Sisa CMCts yang tidak larut kemudian dikeringkan dalam oven. Setelah kering bobotnya ditimbang dan dibandingkan dengan bobot awal. Sedangkan untuk kelarutan kitosan, kitosan dilarutkan dalam asam asetat $1 \%$. Langkah selanjutnya sama dengan yang dilakukan terhadap CMCts.

\section{HASIL DAN BAHASAN}

Hasil penelitian menunjukkan bahwa seluruh produk CMCts yang diperoleh larut air meski dengan tingkat kelarutan yang bervariasi. Kelarutan $\mathrm{CMCts}$ berkisar antara 65,7 sampai $97,9 \%$ (Gambar 1 ). Kelarutan $\mathrm{CMC}$ ts sangat ditentukan oleh keberhasilan reaksi esterifikasi monokloroasetat. Semakin banyak gugus asetil yang mensubtitusi ion $\mathrm{H}^{+}$pada gugus hidroksil maupun amina, maka kelarutan CMCts semakin tinggi. Pada gugus asetil tersebut terdapat ion bebas $\mathrm{O}^{=}$yang akan berikatan dengan ion $\mathrm{H}^{+}$dari $\mathrm{H}_{2} \mathrm{O}$. Suhu dalam hal ini berperan sebagai katalis sehingga reaksi esterifikasi menjadi lebih optimal.

Data derajat asetilasi (DA) menunjukkan bahwa peningkatan suhu menghasilkan CMCts dengan DA yang semakin tinggi. DA CMCts meningkat dari $52,6 \%$ (kitosan) menjadi 61,5-94,2\% (Gambar 2). Hal ini

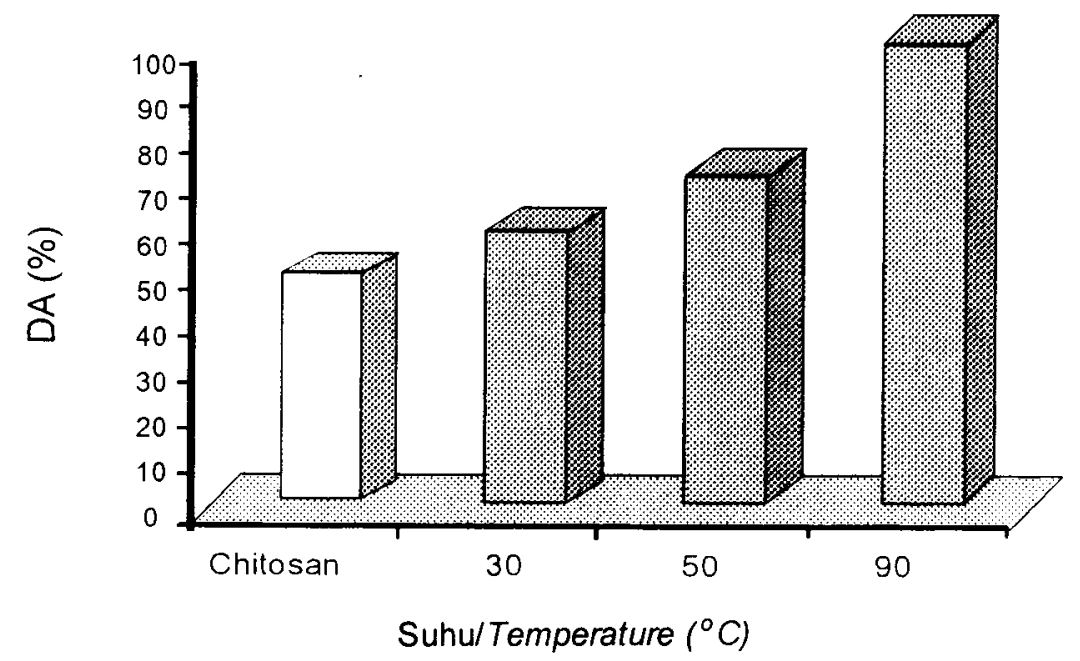

Gambar 2. Derajat asetilasi (DA) CMCts dari berbagai perlakuan suhu dan kitosan pembanding.

Figure 2. Degree of acetylation (DA) of CMCts of various temperature treatment and chitosan as reference. 
menunjukkan terjadinya peningkatan gugus asetil pada CMCts yang berasal dari monokloroasetat yang ditambahkan pada proses esterifikasi. Mengingat suhu dapat berperan sebagai katalis pada reaksi tersebut, maka dengan peningkatan suhu, reaksi esterifikasi menjadi lebih sempurna sehingga jumlah gugus asetil yang mensubstitusi ioh $\mathrm{H}^{+}$juga semakin banyak. Ini sesuai dengan hasil penelitian Alamsyah (2000) yaitu terjadi peningkatan DA sebesar $11 \%$ dari kitosan menjadi CMCts yang proses karboksimetilasinya menggunakan DMAc dan $\mathrm{LiCl}$

Hasil analisis gugus fungsional dengan FTIR pada salah satu perlakuan esterifikasi $\left(50^{\circ} \mathrm{C}\right)$ menunjukkan terjadinya penambahan gugus asetil pada CMCts jika dibandingan dengan kitosan. Hal ini dapat dilihat dengan munculnya puncak (peak) baru pada bilangan gelombang $1154.08 \mathrm{~cm}^{-1}$ dan $1733.47 \mathrm{~cm}^{-1}$ pada spektrum CMCts yang menunjukkan adanya gugus asetil $\left(\mathrm{CH}_{2} \mathrm{COO}\right)$. Puncak ini tidak ditemukan pada spektrum kitosan (Gambar 3). Sementara itu pada bilangan gelombang $1420.68 \mathrm{~cm}^{-1}$ spektrum CMCts terjadi perubahan bentuk puncak. Puncak tersebut merupakan gugus hidroksil/ $\mathrm{OH}^{-}$(Willard et al., 1974;
Nur, 1989). Perubahan ini kemungkinan terjadi sebagai akibat proses esterifikasi. Konfirmasi terhadap puncak ini diperlukan untuk memastikan puncak-puncak yang berada di sekitar bilangan gelombang tersebut. Salah satu program komputer yang dapat memecah puncakpuncak yang tidak tajam (deconvolution) adalah AAnalizer(8) ver 1.02 (Wibowo et al., 2003).

Viskositas CMCts bervariasi antara 45,5 sampai 61,4 cps sementara itu viskositas kitosan sebesar 89,6 cps (Gambar 4). Semakin tinggi suhu esterifikasi, viskositas semakin turun. Hal ini dikarenakan proses pemanasan dapat memutus rantai polimer (depolimerisasi) yang akan menghasilkan kitosan dengan rantai lebih pendek. Semakin pendek jumlah polimer menyebabkan berat molekul semakin rendah, sementara viskositas intrinsik berkaitan dengan berat molekul. Ini sesuai dengan penelitian lain yang mengatakan bahwa peningkatan suhu akan meningkatkan derajat deasetilasi (DD) tetapi menurunkan ukuran molekul (Kyoon et al., 2003). Panas dapat menyebabkan suatu polimer mengalami depolimerisasi, selanjutnya depolimerisasi dapat menyebabkan terjadinya pemecahan rantai molekul

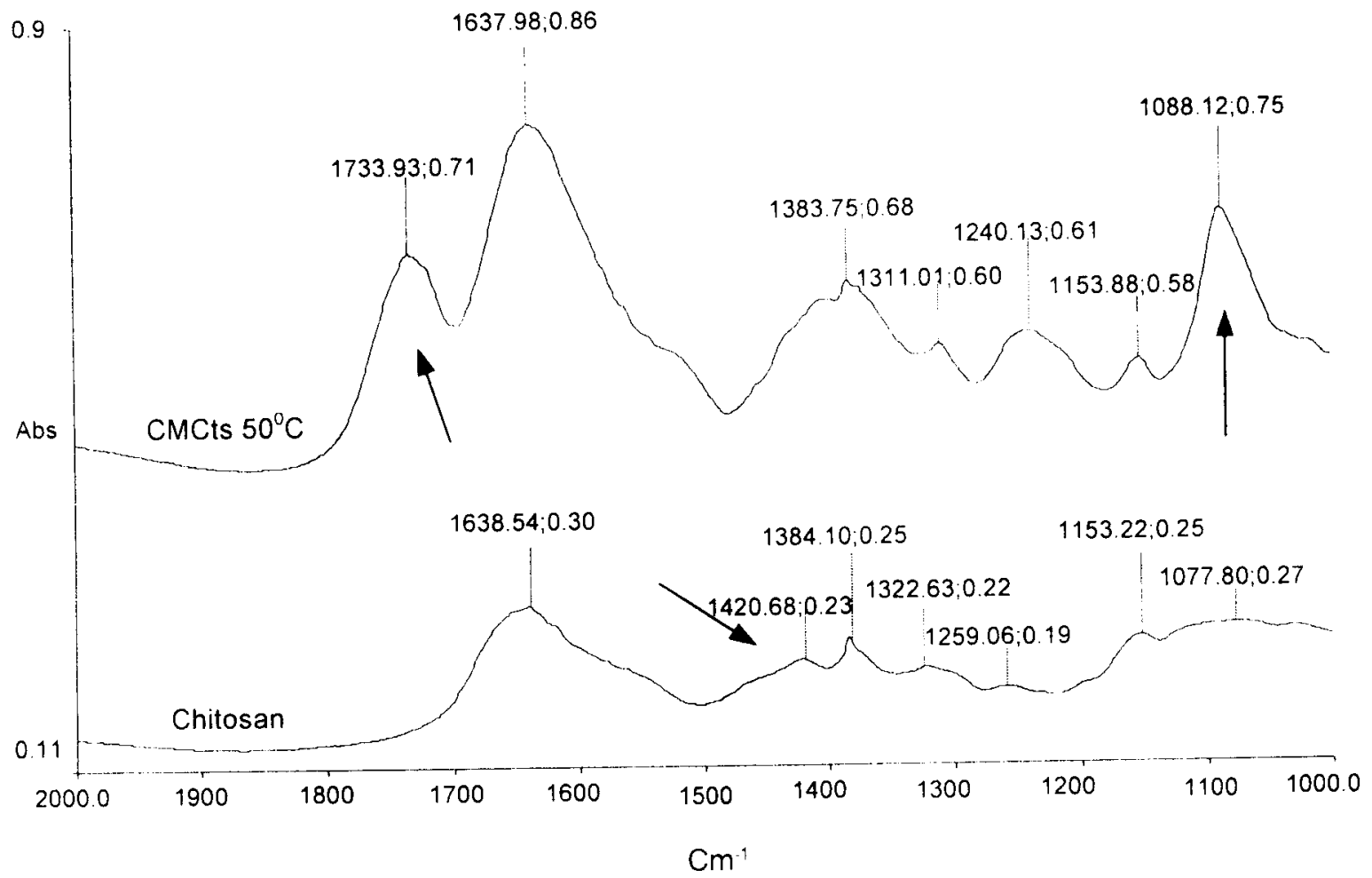

Gambar 3. Spektrum FTIR CMCts- $50^{\circ} \mathrm{C}$ dan kitosan pembanding

Figure 3. FTIR spectra of CMCts $-50^{\circ} \mathrm{C}$ and chitosan as reference 


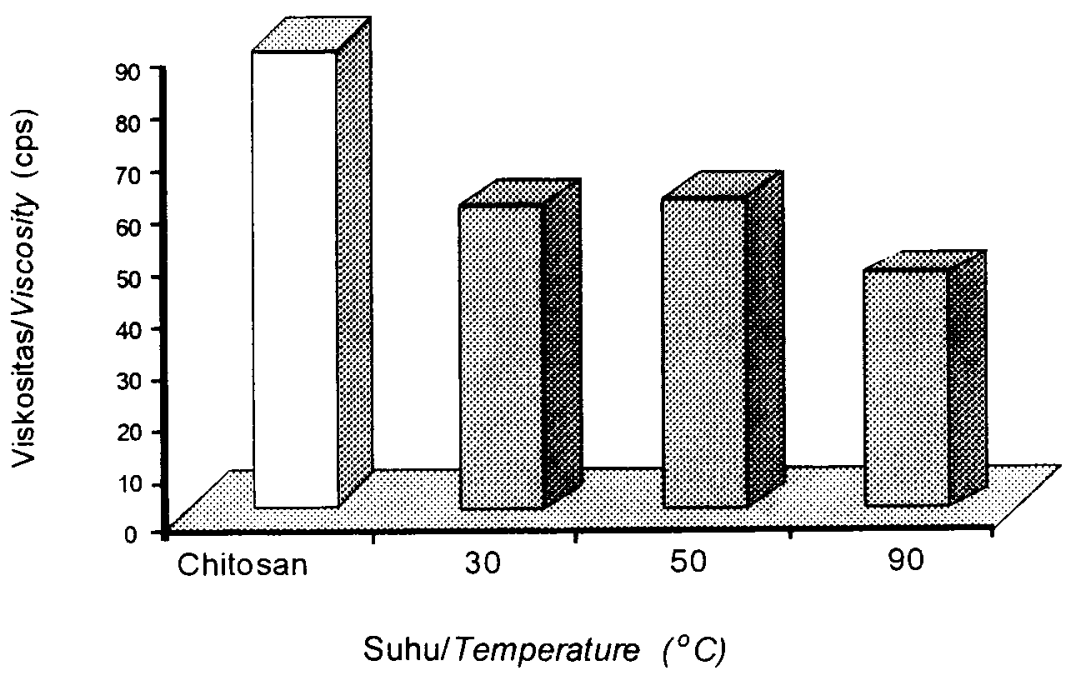

Gambar 4. Viskositas CMCts dari berbagai perlakuan suhu dan kitosan pembanding.

Figure 4. Viscosity of CMCts of various temperature treatment and chitosan as reference.

polimer sehingga berat molekul dan viskositas menurun sejalan meningkatnya suhu (Bastaman, 1989).

Alkalisasi dengan $\mathrm{NaOH} 50 \%$ selama 1 jam dapat menyebabkan terjadinya proses depolimerisasi kitosan. Hal ini sesuai dengan penelitian Bough et al. (1978) yaitu perlakuan alkalisasi dengan $\mathrm{NaOH} 35-$ $50 \%$ dapat menurunkan viskositas dan berat molekul kitosan. Pada penelitian lain pemanasan selama 60 menit pada suhu $121^{\circ} \mathrm{C}$ dapat menurunkan viskositas kitosan sekitar $95 \%$ dan berat molekul sekitar $60 \%$ (Kyoon, et al., 2003).

Rendemen produk berkisar antara 57,0 sampai $98,1 \%$ (Gambar 5 ). Semakin tinggi suhu esterifikasi, rendemen $\mathrm{CMCts}$ juga semakin tinggi. Meningkatnya rendemen disebabkan oleh banyaknya jumlah gugus asetil dari monokloroasetat yang mensubstitusi ion $\mathrm{H}^{+}$pada gugus $\mathrm{OH}$ dan amida kitosan. Dalam hal ini suhu berperan sebagai katalis sehingga proses esterifikasi berlangsung lebih sempurna. Disamping

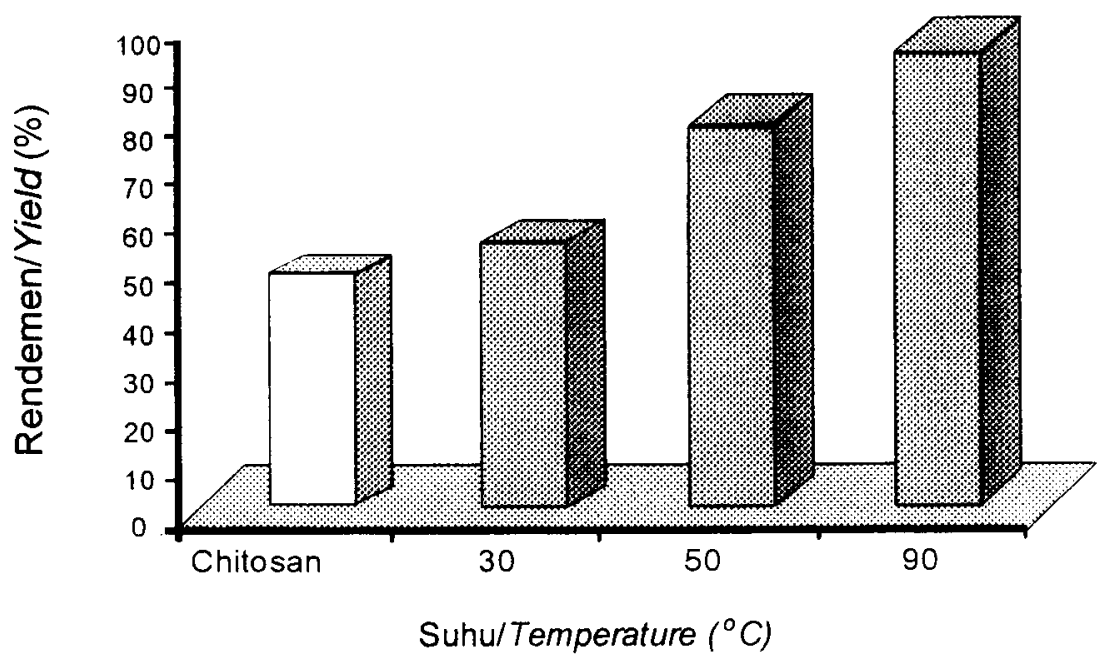

Gambar 5 . Rendemen CMCts dari berbagai perlakuan suhu dan kitosan pembanding Figure 5. Yield of CMCts of various temperature treatment and chitosan as reference. 
suhu, jumlah monokloroasetat juga berpengaruh. Bila jumlah monokloroasetat cukup banyak, maka rendemen CMCts juga akan meningkat. Umumnya jumlah monokloroasetat terhadap kitosan 1:1 dianggap cukup untuk mensubstitusi ion $\mathrm{H}^{+}$.

Pada penelitian ini, meskipun menggunakan suhu yang lebih tinggi $\left(90^{\circ} \mathrm{C}\right)$ namun penggunaan asam monokloroasetat yang lebih murah dan mudah diperoleh ternyata menghasilkan rendemen CMCts yang cukup tinggi. Pada penelitian Alamsyah (2002) yang menggunakan DMAc dan LiCl, antara perbandingan 1:1 hingga 1:2,5 terhadap kitosan tidak berpengaruh nyata terhadap rendemen CMCts. Pada penelitian tersebut rendemen $\mathrm{CMCts}$ yang dihasilkan 98,91-98,97\%. Sementara itu pada penelitian Bader \& Birkholz (1997) rasio monokloroastat yang digunakan adalah 1: 0,9

Data kadar air, nilai $\mathrm{pH}$ dan penampakan CMCts serta kitosan yang digunakan sebagai pembanding pengaturan $\mathrm{pH}$ setelah proses esterifikasi. Pada penelitian ini tidak dilakukan pencucian terhadap CMCts yang dihasilkan. Untuk menghasilkan CMCts dengan $\mathrm{pH}$ netral, penetralan dapat dilakukan pada saat proses pencucian dengan metanol

Perlakuan suhu esterifikasi berpengaruh terhadap penampakan CMCts, yaitu semakin tinggi suhu, penampakan CMCts semakin gelap (Tabel 1). Meskipun memberikan warna yang kurang bagus, peningkatan suhu esterifikasi hingga $90^{\circ} \mathrm{C}$ ternyata dapat menghasilkan CMCts dengan kelarutan dan rendemen yang lebih baik dari perlakuan lainnya. Menurut standar, CMCts sebaiknya berwarna putih atau kuning cerah dan tidak berbau (Anon., 2004a; Anon., 2004b). Faktor ini kemungkinan yang menjadi pertimbangan penggunaan suhu $55^{\circ} \mathrm{C}$ sebagaimana yang digunakan pada penelitian lain, walaupun dengan konsekuensi membutuhkan waktu yang lebih lama yaitu 5 jam (Wuriyandari, 2002).

Tabel 1. Kadar air, $\mathrm{pH}$ dan penampakan CMCts dari berbagai perlakuan suhu dan kitosan pembanding Table 1. Moisture, $\mathrm{pH}$ and appearance of CMCts of various temperature treatment and chitosan as reference

\begin{tabular}{cccc}
\hline $\begin{array}{c}\text { Suhu esterifikasi } \\
\text { Temperature of esterification }\end{array}$ & $\begin{array}{c}\text { Air (\%) } \\
\text { Moisture (\%) }\end{array}$ & $\mathrm{pH}$ & $\begin{array}{c}\text { Penampakan } \\
\text { Appearance }\end{array}$ \\
\hline $30^{\circ} \mathrm{C}$ & 8.98 & 5 & $\begin{array}{c}\text { kuning keputihan } \\
\text { Whitish-yellow } \\
\text { Kuning } \\
\text { Y }\end{array}$ \\
$50^{\circ} \mathrm{C}$ & 10.59 & 5 & $\begin{array}{c}\text { Yellow } \\
\text { kuning kecoklatan } \\
\text { brownish-yellow } \\
\text { putih kekuningan } \\
\text { yellowish-white }\end{array}$ \\
\hline
\end{tabular}

terlihat pada Tabel 1. Kadar air CMCts dari seluruh perlakuan berkisar antara 8 sampai $10 \%$. Kadar air ini telah memenuhi syarat umum CMCts yaitu di bawah 15\% (Anon., 2004b). Kadar air penting karena berkaitan dengan daya simpan produk. Umumnya kapang/jamur akan lebih mudah tumbuh pada produk dengan kadar air di atas 15\% (Winarno, 1989).

Nilai $\mathrm{pH}$ juga turut menentukan kualitas CMCts Semakin mendekati $\mathrm{pH}$ netral maka peluang pemanfaatan CMCts juga semakin luas, karena para pengguna CMCts pada bidang pangan maupun farmasi lebih menyukai CMCts dengan pH netral (Wuriyandari, 2002). CMCts yang dihasilkan dari seluruh perlakuan memiliki $\mathrm{pH} 5$. Nilai $\mathrm{pH}$ ini sesuai dengan perlakuan

\section{KESIMPULAN}

1. Seluruh produk CMCts yang dihasilkan dalam penelitian ini larut air meski dengan tingkat kelarutan yang bervariasi.

2. Berdasarkan parameter kelarutan dan rendemen, perlakuan suhu $90^{\circ} \mathrm{C}$ lebih baik dari perlakuan lain. Namun dari aspek penampakan khususnya warna, memberikan warna yang lebih gelap. Suhu esterifikasi juga berpengaruh terhadap viskositas yaitu semakin tinggi, viskositas semakin rendah.

3. CMCts yang dihasilkan dari seluruh perlakuan memiliki pH 5 


\section{DAFTAR PUSTAKA}

Alamsyah, A. 2000. Modifikasi Pembuatan Kitosan Larut Air. Skripsi. Program Studi Teknologi Hasil Perikanan, Fakultas Perikanan IPB. 36 pp.

Anonymous. 2004a. Carboxymethyl Chitosan. 1 Maret 2004.http://www.greatvistachemicals.com/ biochemicals/carboxymethyl chitosan.html.

Anonymous. 2004b. Specification of Carboxymethyl Chitosan. 1 Maret 2004. http://www.chitogenic.ns .ca /applicat.html.

Bader, H.J. and Birkholz, E. 1997. Teaching chitin chemistry. In Muzzarelli and Peter, M.G. (eds.). Chitin Handbook. European Chitin Society. p. 507-519.

Bastaman, S. 1989. Studies on Degradation and Extraction of Chitin and Chitosan from Prawn Shells. The Department of Mechanical Manufacturing. The Queen's University of Belfast.

Bough, W.A. 1975. Coagulation with chitosan an aid to recovery of by product from egg breaking waste. Poultry Sci. 54:1904.

Bough, W.A., Wu, A.C.M., Campbell, T.E., Holmes, M.S. and Perkin, B.E. 1978. Influence of manufacturing variables of the characteristics and effectiveness of chitosan product. Biotechnol Bioeng. 20:1945-1955.

Chen, X.G and Park, H.J. 2003. Chemical characteristic of O-Carboxymethyl chitosan related to the preparation conditions. J. Carbohydrate Pol. 53(4):355-359.

Davies, D.H, Elson, C.M. and Hayes, E.R. 1988. N,O Carboxymethyl chitosan, $A$ new water soluble chitin derivative. In Skjak-Braek, Anthonsen, G.T. and Sandford, P. (eds.). Chitin and Chitosan: Sources, Chemistry, Biochemistry, Physical Properties and Application. Elsevier Applied Sci. p. 467-472.

Fawzya, Y.N., Basmal, J., Ariyani, F., Indriati, N., Dwiyitno, Zilda, D.S. dan Mulyasari. 2003. Riset Produksi Kitosan dan Derivatnya serta Uji Aplikasinya. Laporan Bagian Proyek Riset Pengolahan Produk dan Sosial Ekonomi Kelautan dan Perikanan T.A. 2003.

Kyoon, N.H., Won, J.N. and Meyers. S.P. 2003. Effect of time/temperature treatment parameters on depolymerization of chitosan. J. Appl. Poly. Sci. 87:18901894
Lembono, S. 1989. Pembuatan Susu Bubuk Kedelai dengan Alat Pengering Semprot. Skripsi. Fakultas Teknologi Pertanian, IPB. Bogor.

Muzzarelli, R.A.A, Rocchetti, R., Stanic, V. and Weckx, M. 1997. Methods for the determination of degree of acetylation of chitin and chitosan. In Muzzarelli, R.A.A and Peter, M.G. (eds.). Chitin Handbook. European Chitin Society. 109-132.

Muzzarelli, R.A.A. 1977. Chitin. Pergamon Press. Oxford, U.K. p309

Nur, M.A. 1989. Bahan Pengajaran Spektroskopi. PAU Pangan dan Gizi. Institut Pertanian Bogor. $141 \mathrm{pp}$.

Ornum, J.1992. Shrimp Waste-Must it be Waste? Infofish International. 6(92): 48-52

Sanford, P.A., 1988. Chitosan: Commercial Uses and Potential Applications. In Skjak-Braek, Anthonsen, G.T. and Sandford, P. (eds.). Chitin and Chitosan Sources, Chemistry, Biochemistry, Physical Properties and Application. Elsevier Applied Science. London and New York. $835 p$

St. Angelo, A.J. and Vercellotti, J.R. 1989. Inhibition of Warmed-Over Flavour and Preserving of Uncured Meat Containing Materials. US Patent.4,871,556.

Wibowo, S., Valazques, S.G., Savant, V. and Tores, J.A. 2003. Effect of Degree of Deacetylation and Molecular Weight of Chitosan on Surimi Wash Water Protein Adsorption. PhD dissertation. Dept. of Food Science and Technology Oregon State University. Corvallis, OR 97331. $123 \mathrm{pp}$

Willard, H.H, Merritt Jr., L.L. and Dean, S.A. 1974. Instrumental Methods of Analysis. $5^{\text {th }}$ ed. D. Val Nostrond Co. New York. $188 \mathrm{pp}$

Winarno, F.G. 1989. Kimia Pangan dan Gizi. PT. Gramedia Pustaka Utama. Jakarta.

Wuriyandari, Y. 2002. Pengembangan Turunan Kitosan yang Larut Air. Fakultas Matematika dan IImu Pengetahuan Alam, Universitas Negeri Jakarta. 16 pp.

Zhai, M, Yoshii, F. and Kume. T. 2003. Studying on antibacterial starch/chitosan blend film formed under the action of irradiation. J. Carbohydrate Pol., 2003, 52(3):311-317 
